\title{
CHEMICAL AND MICROBIal Study Of MANGO AND APRIOT Kernels Seeds and ItS EFfect IN The Beef BURger Products
}

\author{
By \\ Yasser Mohamoud Ebrahim Allewy \\ Faculty of Specific Education, \\ Ain Shames University, \\ Department of Home Economics
}

Research Gournal Specific Fducation

Faculty of Specific Education

glansoura University

ISSUE NO. 42, APRIL. 2016

مجلة بعوث التربية النوعية - جامعة المنصورة

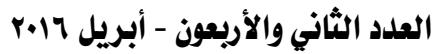




\section{Chemical and Microbial StUdy of Mango and Apriot Kernels Seeds and its effect In The Beef BURger Products}

Yasser Mohamoud Ebrahim Allewy

\section{Abstract}

Meat is a perishable food. both mango and apricot seed kernel extract can use as a natural food additive for extending the shelf-life of a variety of food products. The aim of the present work was to study the antioxidant and antimicrobial effect of ethanol apricot and mango seed kernels extract in beef burger stored at refrigerator temperature for different periods of time. The protein and fat content in apricot kernel extract (ASK) was five time higher than mango kernel extract (MSK). The ASK extract contain unsaturated fatty acids much higher than MSK. Vanillic was the highest amount of total polyphenols compounds found in ethanol mango kernel. While, pyrogallol was the highest compounds found in ethanol apricot kernel. Fresh samples that treated with sodium nitrite tended to have the lowest APC among all different samples investigated immediately after preparation. Both beef burger sample treated with mango and apricot kernels extract have APC lower than untreated samples. Sample treated with mango kernels extract had the lowest APC among all investigated samples after storage for 30 days. Accordingly, both extracts had a high nutritive value and broad antimicrobial spectrum against gram-positive and gramnegative bacteria. Moreover, the active antimicrobial component may be due to polyphenols found in both extracts.

Key words: Mango, Apricot, Kernel, Polyphenols, Antibacterial and Burger

\section{Introduction}

Meat is a perishable food due to high moisture and nutrient contents, almost neutral in $\mathrm{pH}$ so meat is a good medium to be contaminated with microorganisms (Post, 1996). Nitrate and nitrite are additives commonly

\footnotetext{
Faculty of Specific Education, Ain Shames University, Department of Home Economics
} 
used in meat products curing for improvement of colour, flavour and as protection against the growth of microbial such as Clostridium botulinum (Baji, 1984). Nitrite has been implicated in a variety of long term health effects (Walker and Krieble, 1990).

However, increased consumer demand for more natural "preservative free" products during last years has led the food industry to consider the incorporation of natural antioxidants in food products. The use of natural antioxidants has the advantage of being more acceptable by the consumers as these are considered as "no chemical" (El-Bastawesy et al., 2009).

Food antioxidants are compounds or substances that are present naturally in some ingredients or are intentionally added as food additive with the aim of inhibiting product oxidation and to inhibit the microbial growth (Halliwell, 1996).

Apricot kernels contain oil 53\% in the seed and crude protein content 20-25\% (Demir and Cronin, 2005). Apricot are high in health promoting phytonutrients, antioxidants, flavonoids (anthocyanins, flavonols and proanthocyanidins), and polyphenols (Reed, 2002 and Sun et al., 2002). Both water and methanol extracts inhibitory the growth of bacteria (Ghazavi et al., 2008 and Yiğit and Mavi, 2009).

Mango (Mangifera indica L.) is one of the most important tropical fruits. The mango seed kernels contain many macro and micronutrients (Zein et al., 2005). Soong and Barlow (2004) reported that mango seed has a strong antioxidant activity due to its high phenolic compounds content. These authors also observed that mango seed is a good source of phytosterols. Dried mango peel and kernel products can reduce total bacterial count, inhibited coliforms growth, and extended the shelf-life of pasteurized cow milk (Abdalla et al., 2007).

During the processing of mango and apricot, the seed is one of the main by-products. The seeds are not currently utilized for any commercial purpose and are discarded as a waste becoming a source of pollution. Both 
mango and apricot seed kernel extract can use as a natural food additive for extending the shelf-life of a variety of foods products (Ribero et al., 2007).

From the above mentioned data, it could be concluded that both mango and apricot seed kernel extract can use as a natural food additive for extending the shelf-life of a variety of foods products. Moreover, both of mango and apricot seed kernels have many macro and micro nutrient components. Accordingly, the aim of the present work was to study the antioxidant and antimicrobial effect of apricot and mango seed kernels extract in beef burger storage at refrigerator temperature for different periods of time.

\section{Materials and Methods}

\section{Materials:}

\section{- kernels:}

Apricot and mango fruit kernels, were collected from Vitrac Company as by - products. The kernels were removed manually from the seeds, washed with tap water and then dried at $\left(50{ }^{\circ} \mathrm{C}\right)$ in an oven for a week. The dried kernels were crushed using a commercial blender and stored at $\left(-18{ }^{\circ} \mathrm{C}\right)$ in plastic package until analysis and extract the oil (Augustin and Ling, 1987).

\section{- Meat samples:}

Six kilo grams of fresh meat were selected for this part of the study. The meat was collected from retail markets around Cairo City during summer 2014. Those samples collected in sterilized containers and transported to the laboratory under refrigeration and kept at under refrigerated condition until tested.

\section{Preparation Of Beef Burger Formulated :}

Beef burgers were prepared as describe by (Abd-Elhak, et al., 2014)

1. Beef burger formulated was divided into six main leading brands as follow:-

2. The first group is control group (preserved without any preservatives).

3 . The second group is preserved using sodium nitrite only $(250 \mathrm{mg} / \mathrm{kg})$. 
= Chemical and Microbial Study of Mango and Apriot Kernels Seeds and its Effect

4. The third group is preserved using $1500 \mathrm{ppm}$ of ethanol mango kernel extract.

5. The fourth group is preserved using $2500 \mathrm{ppm}$ of ethanol apricot kernel extract.

6. The fifth group is preserved using $750 \mathrm{ppm}$ of mango kernel extract and $125 \mathrm{ppm}$ of apricot kernel extract.

7. 6 .The sixth group is preserved using ( $750 \mathrm{ppm}$ of mango kernel extract $+125 \mathrm{ppm}$ of apricot kernel extract $)+(125 \mathrm{mg}$ of sodium nitrite).

\section{Methods:}

\section{- Apricot Detoxification method:}

Detoxification process has cotyledons of apricot seeds, after conducting a self enzyme hydrolysis of the amygdaline by emulsion enzyme located cotyledons seeds to produce hydrocyanic acid, which is causative to toxicity according to Musa, (2010).

\section{- Detoxification of the full split seeds before oil extraction:}

The full apricots seeds (without grinding) are soaked and cracked in the amount of water by (1:12 w/v) at a temperature of $47^{\circ} \mathrm{C}$ for a period of 30 hour with the change of water every two hours, and after detoxification was removed the water from cotyledons seeds and drying in the oven at a temperature of (50) ${ }^{\circ} \mathrm{C}$ for a week, and were then cotyledons apricot seeds grinding to remove toxicity by laboratory mill (El-Adawy, 1992).

\section{- Preparation of mango and apricot seed kernel extracts}

Powdered kernels were extracted with Absolute ethanol was added to the apricot seed kernel powder at a ratio of 3:1 (v/w) and kept $24 \mathrm{hrs}$ with gentle shaking at $40{ }^{\circ} \mathrm{C}$. Filtered extracts were dried using a rotary evaporator at $45^{\circ} \mathrm{C}$ and stored at $4^{\circ} \mathrm{C}$ for further use (Attia, 2000). 
$\overline{\underline{ }}$

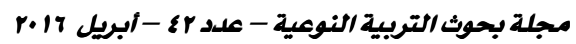

\section{Determination of chemical composition}

Moisture content, crude protein, crude fiber, crude fat and ash of apricot and mango seed kernel powder were determined according to (AOAC 2007). Moreover, carbohydrate were calculated by difference.

\section{Determination of fatty acid}

The fatty acid profile of ethanolic extract of mango and apricot kernels was determined according to ISO 5508 (1990) and ISO 5509 (2000) by gas chromatography (GC) as described by Nath, (1996)

\section{Determination of total phenolic compounds}

The phenolic compounds of ethanolic extract of mango and apricot kernels were determined by HPLC according to the method of Goupy et al. (1999) using HPLC HewlletPackered (series 1050) equipped.

\section{- Preparation of beef burger for microbiological analysis:}

About 50g of beef burger were aseptically weighed and grinded in sterilized hun. One gram of the grinded Beef Burger was transferred into another sterilized mortar for microbiological analysis where nine $\mathrm{ml}$ of sterilized saline solution was added and thoroughly mixed with the beef burgers and this represents 10 dilutions which were then used making further dilution according to Karpinska et al. (2001)

\section{- Determination of total aerobic bacteria count:}

The aerobic and anaerobic plate count were determined following the procedure proposed by the International Commission on Microbiological Specifications for Foods (ICMSF, 1987). This medium was purchased from El-Gomheria Pharmaceutical Company Ameriea, Cairo, Egypt.

Microbiological examination was carried out every seven days interval from storage at refrigerator temperature. All count were done in triplicates. At each sampling time, the stored bags 
were analyzed microbiologically according to the procedure recommended by the International Commission on Microbiological Specification for Foods (ICMSF). Serial dilutions were prepared as described by (ICMSF, 1987)

\section{Results and Discussion}

The moisture content of dried apricot seed kernels (ASK) was approximately $2.4 \%$. Crude protein, total fat, crude fiber, carbohydrates and ash contents of ASK were found to be 26.5, 53.2, 13.5, 2.421 and $1.9 \%$ on a dry weight basis, respectively (table 1).

Table (1): Chemical composition percentage of apricot and mango kernels powder.

\begin{tabular}{|c|c|c|c|c|c|c||}
\hline Samples & Moisture & Fat & Protein & fiber & Ash & Carbohydrate \\
\hline \hline ASK & 2.380 & 53.261 & 26.522 & 13.520 & 1.896 & 2.421 \\
\hline MSK & 5.632 & 11.356 & 5.911 & 11.140 & 2.225 & 63.736 \\
\hline
\end{tabular}

*(ASK) Apricot seed kernels

* (MSK) Mango seed kernels

The protein content reported in the current study was close to that reported by Femenia et al., 1995 which reported that protein content of apricot kernel ranged from 14.1 to $45.3 \%$. The chemical composition of apricot seeds kernels results obtained in this study were in general agree with the many previous studies (Gupta et al., 2012). Moreover, cured protein is close to that obtained in Lazos study which reported that the cured protein in apricot kernel was $21.2 \%$ (Lazos, 1991).

The result of MSK obtained in the current study were in general agreement with the data obtained by (Zein et al., (2005), Abdalla et al., (2007) and Ashoush and Gadallah (2011). The MSK total lipid content obtained in this study was higher than that showed by (Youssef, 1999).

Total fat for apricot kernel detected in this study was in the range of total lipid obtained in other study which found the oil yields from apricot kernels ranged from $42.2 \%$ to $57.2 \%$ (Musa et al., 2010).

It should be noted that, the protein and fat content in ASK was five time higher than MSK. While, the carbohydrates content in MSK were 
much higher than ASK. This results is within with that obtained by Abdalla (2007) who confirmed that mango seeds kernel contained low amount of crude protein. Accordingly, the results indicated that the studied apricot kernel flours considered an important new protein sources. The previous opinion is agree with El-Safy et al., 2012.

From the results illustrated in table (1), it was observed that the ASK was more nutritive than MSK because it's content more protein, fat and fiber. Accordingly, the investigated kernels flours can be used as an effective additive in foods such as meat and cereal products specially ASK flour.

From the previous chemical analyses, it could be concluded that, both of powder material contain fat with different concentration. Accordingly this study aimed to prepare alcohol extract from both apricot and mango seeds kernel. Then fatty acid composition was analyzed and the results were illustrated in table (2).

It should be noted that, the unsaturated fatty acid for apricot seed kernels extract was $91.5 \%$ and consisted mainly of oleic and linoleic acids. The saturated fatty acid content for apricot seed kernels extract was only $8.5 \%$, with major fatty acid of palmitic and it consists $5.36 \%$. Accordingly, the ability of some unsaturated fatty acids to reduce serum cholesterol level may focus attention on for spricot seed kernels extract (Milosevic et al., 2010). The results indicated that the apricot and kernel seeds extract contained several fatty acids such as Palmitic acid, Oleic acid and Linoleic acid. This result was in general closed to several studies (Lazos, 1991 and Manzoor et al, 2012). 
= Chemical and Microbial Study of Mango and Apriot Kernels Seeds and its Effect

Table (2): percentage of Fatty acids composition of Apricot and Mango seed kernels extract

\begin{tabular}{|c|c|c|c|c|}
\hline & \multicolumn{2}{|c|}{ Fatty acids } & Apricot seed & $\begin{array}{c}\text { Mango seed } \\
\text { kernels extract } \%\end{array}$ \\
\hline \multirow{7}{*}{ 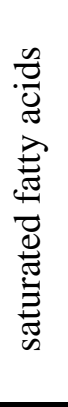 } & Palmitic acid & C16:0 & 5.36 & 4.68 \\
\hline & Margaric acid & $\mathrm{C} 17: 0$ & 0.03 & ND \\
\hline & Stearic acid & $\mathrm{C} 18: 0$ & 0.77 & 44.20 \\
\hline & Arachidicacid & C20:0 & 1.50 & 2.81 \\
\hline & Behenic acid & $\mathrm{C} 22: 0$ & 0.01 & 0.17 \\
\hline & Lignoceric acid & $\mathrm{C} 24: 0$ & 0.06 & ND \\
\hline & \multicolumn{2}{|l|}{ Total } & 8.5 & 51.86 \\
\hline \multirow{6}{*}{ 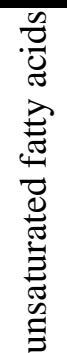 } & Palmitoleic acid & $\mathrm{C} 16: 1$ & 1.03 & 0.04 \\
\hline & Ginkgolic acid & C17:1 & 012 & ND \\
\hline & Oleic acid & C18:1 & 63.87 & 42.05 \\
\hline & Linoleic acid & $\mathrm{C} 18: 2$ & 26.10 & 4.96 \\
\hline & & C20:1 & 0.61 & 0.24 \\
\hline & \multicolumn{2}{|l|}{ Total } & 91.5 & 47.86 \\
\hline
\end{tabular}

In general, stearic acid was the main saturated fatty acid in, while oleic acid was the major unsaturated fatty acid in mango seed kernels. This result was in within with many studies which reported that the main fatty acids of total lipids were stearic acid (40-42\%) and oleic (47-48\%) of total fatty acids, and they together constituted $87-88 \%$ of total fatty acids (Helmy (1998) and El-Soukkary et al., (2000). Moreover, the current results were in agreement with earlier studies study which reported that the major fatty acids of Apricot extract were oleic, linoleic and palmitic (E1-Aal, Rahma and Khalil (1986) and (Manzoor et al.,(2012)).

From the above mentioned data, it could be concluded that, the Apricot seed kernels extract contain unsaturated fatty acids much higher than Mango seed kernels extract. On contrast, Mango seed kernels extract contain saturated fatty acids tended to have fat content approximately 6.5fold higher than Apricot seed kernels extract. 
Researchers have shown that foods rich in unsaturated fatty acids decrease risk of arrhythmias (abnormal heartbeats), which can lead to sudden death. Unsaturated fatty acids also decrease triglyceride levels, slow growth rate of atherosclerotic plaque, lower blood pressure and a possible lowering of cardiovascular disease (CVD) mortality (AHA, (2003) and Hooper et al., (2004)). Accordingly, Apricot seed kernels extract has much power effect for reduction the risk of various forms of cardiac disease than Mango seed kernels extract.

Third: Flavonoids composition of ethanolic extract for apricot and mango seed kernels

Phenolic compounds has potential as cancer fighting molecules and many other health functions (Ramos, 2007 ).Though phenolic compounds are present in almost all foods of plant origin. fruits, vegetables, and beverages are the major sources of these compounds in the human diet (Hertog, et al., 1995). 
= Chemical and Microbial Study of Mango and Apriot Kernels Seeds and its Effect

Table (3): Phenolic compounds of apricot and mango seed kernel extract

\begin{tabular}{|c|c|c|}
\hline phenolic compounds & $\begin{array}{c}\text { Mango seed kernel } \\
\text { extract }(\mathbf{p p m}) \\
\end{array}$ & $\begin{array}{c}\text { Apricot seed kernel } \\
\text { extract }(\mathbf{p p m}) \\
\end{array}$ \\
\hline Gallic & 754.34 & 11.40 \\
\hline Pyrogallol & 3182.66 & 1278.78 \\
\hline 4-Amino-benzoic & 18.30 & 11.27 \\
\hline Protocatchchuic & 144.88 & 57.82 \\
\hline Catechein & 321.05 & 190.37 \\
\hline Chlorogenic & 347.31 & 72.40 \\
\hline Catechol & 12228.52 & 127.30 \\
\hline Epicatechein & 1640.94 & ND \\
\hline Caffeine & 244.72 & 14.67 \\
\hline p-oh-benzoic & 947.56 & 319.22 \\
\hline Caffeic & 155.72 & 124.88 \\
\hline Vanillic & 13119.49 & 57.25 \\
\hline ferulic & 146.40 & 206.82 \\
\hline Iso- ferulic & 44.38 & 152.84 \\
\hline e-vanillic & 1459.53 & 269.39 \\
\hline ellagic & 539.51 & 221.55 \\
\hline Alpha-coumaric & 11.37 & 23.33 \\
\hline benzoic & 122.60 & 559.54 \\
\hline salyciic & 363.95 & 91.07 \\
\hline 3,4,5 Methoxy cinnamic & 9.01 & 52.41 \\
\hline coumarin & 56.95 & 18.80 \\
\hline p- coumaric & 102.18 & 19.71 \\
\hline cinnamic & 1.77 & 10.01 \\
\hline
\end{tabular}

The phenolic compounds $(\mathrm{mg} / 100 \mathrm{~g})$ of ethanolic extracts for mango and apricot kernel analyze by high- performance liquid chromatography (HPLC) against standard compounds. Data in table (3) showed that Vanillic was the highest amount of total polyphenols compounds found in ethanol mango kernel. While, Pyrogallol was the highest compounds found in 
ethanol Apricot kernel. Epicatechein acid was found only in mango kernel extract. On the other hand, cinnamic acid was the lowest amount of total polyphenols found in both apricot and kernel. These results somewhat agree with those reported by Mohamed and Girgis (2005) and (Puravankara et al. 2000).

In general, all polyphenols component were higher in mango kernel extract as compared to apricot kernel extract. Based on the HPLC analysis, and by comparison with standards, 23 polyphenols could be identified or characterized in mango kernel extract, and 22 polyphenols in apricot extract. The polyphenols component isolated from mango kernel in this study were much higher than that obtained in Puravankara et al., (2000) study, that identified six phenolic compounds in mango seed extracts, especially Gallic acid. This difference may be due to the different in mango category. Moreover, Mohamed and Girgis (2005) found that, separated six phenolic compounds, mainly coumaric, vanillin and ferulic acid.

From the above mentioned data it could be concluded that, mango kernels proved a source of phenolics. This result is applicable with other study (Pura-vankara, et al., 2000). From table 3 it be concluded that mango kernel is a rich sources of polypheols components. This finding is within with the finding reported by (Abdalla et al., 2007).

The average of total phenolic component obtained in this study was close to the value of total phenolic obtained in the recent studies which determine total phenolic (TPC) of leaves, peels, stem bark, and kernel of different mango varieties, and total flavonoid contents (TPC) in ranged from 630.89 to $11600.80 \mathrm{mg}$ GAE/100g dry weight (Choudhary and Swarnkar, 2011 and Badmus et al., 2012).

Pyrogallol is predominating in both extracts. Pyrogallol is antioxidant and anti-inflammatoryand protected against chemically-induced liver toxicity in vivo. Most of polypheols component isolated from ethanol mango and apricot kernels extract constitute a significant part of a healthy diet due to their high antioxidant, anti-inflammatory and antimicrobial capacities (Heim, et al., 2002). Moreover, natural poltphenols are safe for 
use as a food additive, functioning as an antioxidant in some countries, including Japan.

From the above mentioned data concluded that mango and apricot kernel extract can be used as a new natural antioxidant to improve the oxidative stability of some foods. This opinion is within with Soong et al., (2004) results which reported that mango seed has a strong antioxidant activity due to its high phenolic compounds (Tanaka, 1999), rich in phytochemicals (Ashoush and Gadallah, 2011).

Thus utilization of mango and apricot kernels for extraction of oils seems to be a profitable proposition for the efficient utilization of stones/pits which otherwise is thrown as a waste. This opinion is agree with Gupta and Sharma.(2009), Özcan .(2010) and Manzoor, et al (2012) opinions.

Minced meat is usually a very perishable food so prolonging its shelf life is an important objective for producers. Accordingly, this study aimed to try extended the shelf life of one product of minced meat (beef burger) by adding natural extract.

Table (4): Total aerobic plate counts (APC) exhibited by beef burgers treated with mango and apricot kernels extract after storage at refrigerator temperature for different storage periods (cfu/g).

\begin{tabular}{|c|c|c|c|c|c||}
\hline Storage periods & Zero time & $\mathbf{7}$ days & 14 days & 21 days & 30 days \\
\hline \hline Control & $4 \times 106 \mathrm{c}$ & $7.3 \times 106 \mathrm{c}$ & $13.6 \times 106 \mathrm{c}$ & $14.6 \times 106 \mathrm{~d}$ & $15 \times 106 \mathrm{c}$ \\
\hline Sodium Nitrite & $1 \times 106 \mathrm{a}$ & $1.6 \times 106 \mathrm{ab}$ & $1.3 \times 106 \mathrm{a}$ & $1.3 \times 106 \mathrm{a}$ & $9 \times 105 \mathrm{ab}$ \\
\hline Mango seed kernels extract & $2 \times 106 \mathrm{~b}$ & $1 \times 106 \mathrm{a}$ & $3 \times 105 \mathrm{~b}$ & $8.5 \times 105 \mathrm{c}$ & $6 \times 105 \mathrm{a}$ \\
\hline Apricot seed kernels extract & $2.3 \times 106 \mathrm{~b}$ & $1 \times 106 \mathrm{a}$ & $1 \times 106 \mathrm{a}$ & $2 \times 106 \mathrm{ab}$ & $9 \times 105 \mathrm{ab}$ \\
\hline $\begin{array}{c}\text { Mango and apricot seed } \\
\text { kernels extraction }\end{array}$ & $2 \times 106 \mathrm{~b}$ & $1 \times 106 \mathrm{a}$ & $1 \times 106 \mathrm{a}$ & $2 \times 106 \mathrm{ab}$ & $1 \times 106 \mathrm{~b}$ \\
\hline $\begin{array}{c}\text { (Mango and apricot seed } \\
\text { kernels extraction) }+(\text { Sodium } \\
\text { Nitrite) }\end{array}$ & $3.6 \times 106 \mathrm{c}$ & $2 \times 106 \mathrm{~b}$ & $4 \times 106 \mathrm{~b}$ & $3 \times 106 \mathrm{~b}$ & $1 \times 106 \mathrm{~b}$ \\
\hline \begin{tabular}{c} 
Commercial samples \\
\hline
\end{tabular} & $34 \times 106 \mathrm{~d}$ & $73 \times 106 \mathrm{~d}$ & $29 \times 106 \mathrm{~d}$ & $20.3 \times 106 \mathrm{e}$ & $25 \times 106 \mathrm{~d}$ \\
\hline
\end{tabular}


The total bacteria counts in beef burgers before and after addition of mango and apricot kernels extract storage for different periods of time at refrigerator temperature were shown in table (5). The results showed that, the total bacterial counts in fresh (untreated) beef burgers were $4 \times 10^{6} \mathrm{cfu} / \mathrm{g}$. Fresh samples that treated with sodium nitrite tended to have the lowest APC among all different samples investigated immediately after preparation. Even, there is significant differences have been observed between this samples and other investigated samples.

Both beef burger samples treated with mango and apricot kernels extract have APC lower than untreated samples, even statistical significant differences have been observed between them. Moreover, commercial samples tended to have the highest APC among all samples investigated immediately after preparation.

Samples treated with half amount of sodium nitrite and half amount of both kernel ethanol extract had APC higher than samples treated with pure extracts from mango and apricot kernels and sample treated with sodium nitrite. Even, statistical significant were observed between them.

Aerobic plate count (APC) for most of investigated samples after storage for different periods of time were increased with increasing the periods of time.

In weekly investigation, commercial samples tended to have the highest APC among all treated samples after storage at refrigerator temperature. It may be due to this sample had the highest APC before storage.

Aerobic plate count (APC) for control sample was higher than all another treated samples investigated after storage for different periods of time. It means that sodium nitrite, mango kernel extract and apricot kernel extract can play a positive role as antibacterial.

Sample treated with mango kernels extract had the lowest APC among all investigated samples after storage for 30 days, even lower than samples treated with sodium nitrite. After seven days of storage there no statistical significant difference were observed between samples treated with 
sodium nitrite or treated with ethanol mango or/and apricot kernels extract. This result agree with Gadallah and abdel Fattah (2011).

From the above mentioned data it could be concluded that mango and apricot kernels extract reduced aerobic plate of beef burgers, even after storage for 30 days as refrigerator temperature. These results might be due to a variety of phenolic compounds such as falvonds and gallotannins present in the mango and apricot kernels extract. This observation is agree with those report by Pura-vankara et al (2000), Kabuki et al. (2000), Engels et al (2009) and (Tian et al., 2009).

It is striking that the mean total APC present in investigated beef burger is lower than the recommendation safety limit proposed by Egyptian Standards which proposed that total APC in beef burger should not excess than $10^{6} \mathrm{cell} / \mathrm{g}$ (E.O.S, 2005).

From the above mentioned data it be concluded that the above results apricot, and mango kernels are rich in nutrients and could be utilized for cooking and some food products. These results reported that the both extracts had a broad antimicrobial spectrum against gram-positive and gram-negative bacteria. Moreover, the active antimicrobial component may be due to polyphenols found in both extracts.

\section{References}

- Abdalla, A.; Darwish, S.; Ayad, E.; and El-Hamahmy, R. (2007). Egyptian mango by-product 2: Antioxidant and antimicrobial activities of extract and oil from mango seed kernel. Food Chemistry, 103(4):1141-1152.

- Abd Elhak N.A.; Ali S.E and Zakna (2014). Innovative modification of traditional burger, Egypt. J. Agric. Res., 92 (3): 995.

- AHA Nutrition Committee. (2003). Omega-3 fatty acids and cardiovascular disease new recommendations from the American Heart Association. Arteriosclerosis, thrombosis, and vascular biology, 23(2), 151-152.

- AOAC (2007). Official Methods of Analysis of AOAC International, 18th ed. Association of Official Analytical Chemists, Washington,DC. USA.

- Augustin M.A. and Ling E.T . (1987). Composition of mango seed kernel. Pertanik Journal of Science and Technology , 10, 53-59. 
- Ashoush, I. and Gadallah, M. (2011). Utilization of Mango Peels and Seed Kernels Powders as Sourcesof Phytochemicals in Biscuit. World Journal of Dairy and Food Sciences, 6(1): 35-42.

- Attia, R.S. (2000). Studies on apricot seeds (Prunus armeniaca) to use as anonconventional source for edible oil and protein. Journal of Agricultural Science. Mansoura University, 11, 6994 - 7009.

- Babji A. and Abdullah A. (1984). Nitrite Content of Some Foods in Malaysia. Pertanika , 7(2), 39-41..

- Badmus, J., Adedosu, T., Fatoki, J., Adegbite, V., Adaramoye, O. and Odunola, O. (2011). Lipid peroxidation inhibition and antiradical activities of some leaf fractions of Mangifera indica. Acta Pol Pharm, 68, 23-29.

- Choudhary, R. \& Swarnkar, P. (2011). Antioxidant activity of phenolic and flavonoid compounds in some medicinal plants of India. Natural product research, 25(11), 1101-9.

- Demir, A., and Cronin, K. (2005). Modelling the kinetics of textural changes in hazelnuts during roasting. Simulation Modelling Practice and Theory., 13(2): 97-107.

- El-Adawy, T. A. I. (1992). Chemical technological studies and characterization of apricot kernel protein. Ph.D. thesis, Faculty. of Agriculture, Minufiya Univ. Egypt.

- El - Bastawesy Amal, M.; Ragaa, H. M. and El Refai, A. A., (2009). Chemical and biological evaluation of rosemary (Romaine's officinal is L.) leaves volatile oil and its methonolic extract. Annals Agric. Sie. 54 (2): 397-415.

- El-Aal, M.A.; Khalil, M. K., and Rahma, E. H. (1986). Apricot kernel oil: Characterization, chemical composition and utilization in some baked products. Food chemistry, 19(4): 287-298.

- El-Safy, F.; Salem, R. and Abd El-Ghany, M. (2012). Chemical and nutritional evaluation of different seed flours as novel sources of protein. World Journal of Dairy \& Food Scie

- El-Soukkary F.; El-Sahn M. and Mohamed H. (2000). Physico- chemical and nutritional evaluation of mango seed kernel and its utilization for pan bread supplementation. nces, 7(1), 59-65

- E.O.S (2005). Egyptian Organization for Standards and Quality Control 
= Chemical and Microbial Study of Mango and Apriot Kernels Seeds and its Effect

- Engels, C.; Knodler, M. A.; Zhao, Y.; Carle, R.,; Ga“nzle, M. and Schieber, A. (2009). Antimicrobial activity of gallotannins isolated from mango (Mangifera- indica L.) kernels. Journal of agricultural and food chemistry, 57(17): 7712-7718.

- Femenia, A.; Rossello, C.; Mulet, A., and Canellas, J. (1995). Chemical composition of bitter and sweet apricot kernels. Journal of Agricultural and Food Chemistry, 43(2): 356-361.

- Gadallah, M. and Fattah, A. (2011).The Antibacterial Effect of Mango Seed Kernel Powder in Minced Beef During Refrigerated Storage . World Journal of Diary \&Food science, 6(2), 219-288.

- Ghazavi, A.; Abtahi, H.; Karimi, M.; Mollaghasemi, S., and Mosayebi, G. (2008). Antimicrobial activities of water and methanol extracts of bitter apricot seeds. Journal of Medical sciences, 8(4): 433-436.

- Goupy, P.; Hugues, M.; Boivin, P., and Amiot, M. (1999). Antioxidant composition and activity of barley (Hordeum vulgare) and malt extracts and of isolated phenolic compounds. Journal of the Science of Food and Agriculture, 79(12), 1625-1634.

- Gupta, A., and Sharma, P (2009). Standardization of technology for extraction of wild apricot kernel oil at semi-pilot scale. In Biological Forum , 1(1), 51-64.

- Gupta, A.; Sharma, P.; Tilakratne, B. and Verma, A. (2012). Studies on physico-chemical characteristics and fatty acid composition of wild apricot (Prunus armeniaca Linn.) kernel oil. Indian Journal of Natural Products and Resources, 3(3): 366-370.

- Halliwell, B.(1996). Antioxidants in human health and diseases. Annual Review of Nutrition, 16(1-2): 33-50.

- Heim, K.; Tagliaferro, A. and Bobilya, D. (2002). Flavonoid antioxidants: chemistry, metabolism and structure-activity relationships. The Journal of nutritional biochemistry, 13(10): 572-584.

- Helmy, H.(1998). Utilization of mango seed oil in soup production. Egyptian Journal Applied Science, 13(12): 130-140.

- Hooper, D. and Dukes, J. (2004). Overyielding among plant functional groups in a long-term experiment. Ecology Letters, 7(2): 95-105. 
- Hertog, M.; Kromhout, D.; Aravanis, C.; Blackburn, H.; Buzina, R.; Fidanza, F.; Ciampaoli, S.; Jansen, A.; Menotti, A.; Nedeljkovic, S.; Pekkarinen, M.; Simic, B. S.; Toshima, H.; Feskens, E; Hollman, P., and Katan, M,.(1995). Flavonoid intake and long-term risk of coronary heart disease and cancer in the seven countries study. Arch. Int. Med. 155(4): 381386.

- Hertog, M., Feskens, E., Kromhout, D., Hollman, P. and Katan, M. B. (1993). Dietary antioxidant flavonoids and risk of coronary heart disease: the Zutphen Elderly Study. The Lancet, 342(8878): 1007-1011.

- ICMSF (1987). International Commission on Microbiological Specifications for Foods.

- Kabuki, T.; Nakajima, H.; Arai, M.; Ueda, S.; Kuwabara, Y. and Dosako, S. I. (2000). Characterization of novel antimicrobial compounds from mango (Mangifera indica L.) kernel seeds. Food chemistry, 71(1): 61-66.

- Karpinska, M.; Borowski, J. and Danowska, O. M. (2001). The use of natural antioxidants in ready to serve food. Food Chemistry., 72 (1): 5-9.

- Lazos, E. (1991). Composition and oil characteristics of apricot, peach and cherry kernel. Grasas y Aceites, 42(2): 127-131.

- Manzoor, M.; Anwar, F.; Ashraf, M.; and Alkharfy, K.M. (2012). Physicochemical characteristics of seed oils extracted from different aprico (Prunus armeniaca L.) varieties from Pakistan. grasas y aceites, 63(2): 193-201.

- Milosevic, T.; Milosevic, N.; G lisic, I. and Krska, B. (2010). Characteristics of promising apricot (Prunus armeniacaL.) genetic resources in Central Serbia based on blossoming period and fruit quality. Hort. Sci. Prague, 37(2): 46-55.

- Mohamed, E. and Girgis, A. (2005). Utilization of mango seed kernels for improving stability of some oils and biscuit production. Journal of Agricultural and Science, Mansoura University, 30(8): 4625-4636.

- Musa, M. (2010). Properties of Apricot Kernel and Oils as Fruit Juice Processing Waste. Food and Nutrition Sciences, 1(2): 31-37.

- Nath M, S. C.; Pathak, M. G. and Baruah, A. (1996). Benzyle benzoate, the major component of leaf and steam bark oil Cennamoumum zelyanicum blum. J. Esent. Oil Res. 8: 327 - 331. 
- Post, R. (1996). Regulatory perspective of the USDA on the use of antimicrobials and inhibition in foods. Trends in food microbiology. Proceedings of International life Science Inst. Symposium 1994 IAMFES Annual Meeting San Antonio, Texas USA, 31 July, 3 August.

- Post, R. (1996). Regulatory perspective of the USDA on the use of antimicrobials and inhibitors in foods. Journal of food protection, 78-81.

- Puravankara, D.; Bohgra, V.; and Sharma, R. (2000). Effect of antioxidant principles isolated from mango (Mangifera indica L.) seed kernels on oxidative stability of buffalo ghee (butter-fat). Journal of the Science of Food and Agriculture 80(4): 522-526.

- Ramos, S. (2007). Effects of dietary flavonoids on apoptotic pathways related to cancer chemoprevention. The Journal of nutritional biochemistry, 18(7), 427442.

- Reed, J. (2002). Cranberry flavonoids, atherosclerosis and cardiovascular health. Critical Reviews in Food Science and Nutrition, 42(S3): 301-316.

- Ribeiro, S., Queiroz, J., de Queiroz, R., Campos, F. \& Sant'Ana, H. (2007). Antioxidant in mango (Mangifera indica L.) pulp.Plant Foods for Human Nutrition, 62(1), 13-17.

- Soong, Y.; Barlow, P. and Perera, C. (2004). A cocktail of phytonutrients: identification of polyphenols, phytosterols and tocopherols from mango (Mangifera indica L.) seed kernel. In IFT annual meeting, 12-16 July.

- Stanojevic D.L.; Comic O.S.; and Solujic S.S. (2009). Antimicrobial effects of sodium benzoate, sodium nitrite andpotassium sorbate and their synergistic action in vitro. Bulg. J. Agric. Sci., 15: 307-311.

- Sun, J.; Chu, Y. and Liu, R. (2002). Antioxidant and antiproliferative activities of common fruits. Journal of Agricultural and Food Chemistry, 50(25): 74497454.

- Tian, F., Li, B., Ji, B., Zhang, G., and Luo, Y. (2009). Identification and structure-activity relationship of gallotannins separated from Galla chinensis. LWT-Food Science and Technology, 42(7): 1289-1295.

- Walker, J., \& Krieble, V. ,(1990). The hydrolysis of amygdalin by acids. Part I. Journal of the Chemical Society, 95(11), 1369-1377. 
- Yiğit, N., and Mavi, A. (2009). Antioxidant and antimicrobial activities of bitter and sweet apricot (Prunus armeniaca L.) kernels. Braz J Med Biol Res. Apr;42(4):346-52

- Youssef, A. (1999 ).Utilization Of The Seeds Of Mango Processing Wastes As A Secondary Source Of Oil And Protein. Alexandria Journal of Agricultural and Research, 44(3), 149-166.

- Zein, R.; EL Bagoury, A.; and Kassab, H. (2005).Chemical and nutritional studies on mango seed kernels. Journal of Agricultural Science, Mansoura University, 30(6), 3285-3299. 


\section{دراسة كيسيائية و هيكروبية لبذور المشهش و المانجو و تأثيره علي البيف برجر} ياسر محمود ابراهيم علوي

$$
\text { الملخص العربي }
$$

ان اللـحـوم مـن الاطعمــة القابلـة للتلـف لـذلك فاننـا نضيف بعـض المضيفات الطبيعيـة

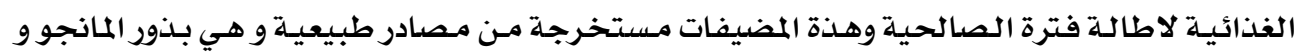
بذور المشهم و كان الهدف من تلـك الدراسـة هـو استخراج مـضادات الاكسـدة و مـضادات الميكروبـات

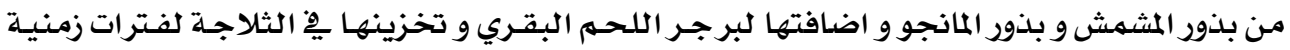
مختلفة و توصلت النتائج الي ان محتوي البروتين و الدهون المستخرج مـن نوي المشمش اعلسي خمسـة

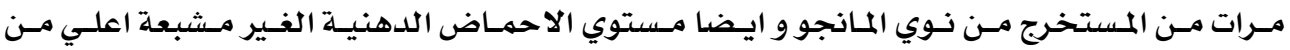

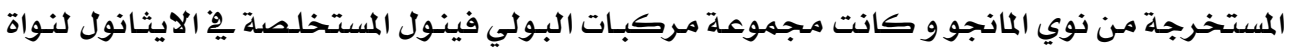
المانجو اكبر مـن مثلتهـا يٌْ بـذور المشهش. تم تحضير العينـات مـن البرجـر البقـري مـع اضـافة الحـد الادني لنترات الصوديوم لعينـة مـن العينات و عولجت باقي العينات بزيوت بذر المشمش و المانجو فوجـد ان العد الكلي لجميـع العينات اللتي عولجت بمستخلصـات بذور المشهش و المانجو و حفظت لمدة ·ـ يـوم هِخ الثلاجـة اقل من العينات اللتي لم الكنترول التي لم يضف اليها أي اضافة حيث قل العدد الاجمـالي للميكروبات العنقودية من لحم البرجر حتي بعد التخزين لمدة ·ب يوم يِّ الثلاجهة بالإضـافة الي ارتفـاع

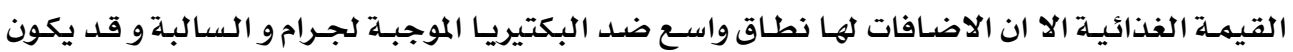
راجـع لوجود البولي فينول الموجود يِ مستخلصدات بذور المشمش و المانجو . 